among patients with HIV infection. Ann Intern Med 1992:117:177183.

7. Pearson ML, Jereb JA, Frieden TR, et al. Nosocomial transmission of multidrug resistant Mycobacterium tuberculosis. Ann Intern Med 1992;117:191-196.

8. Catanzara A. Nosocomial tuberculosis. Am Rev Resp Dis 1982;125:559-562.

9. Frampton MW. An outbreak of tuberculosis among hospital personnel caring for a patient with a skin ulcer. Ann Intern Med 1992;117:312-313.

10. Hutton MD, Steao WW, Cauthento M, et al. Nosocomial transmission of tuberculosis associated with a draining tuberculous abscess. J Infect Dis 1990;161:286-95.

11. Haley CE, McDonald RC, Rossi L, et al. Tuberculosis epidemic among hospital personnel. Infect Control Hosp Epidemiol 1989:10:204-210.

12. Centers for Disease Control. Guidelines for Prevention of TB Tram-mission in Hospitals. Atlanta, GA: U.S. Department of
Health Human Services; 1982. U.S. Department of Health Human Services publication CDC 82-8371.

13. Centers for Disease Control. Guidelines for preventing the transmission of tuberculosis in health care settings, with special focus on HIV-related issues. MMWR 1991;39:1-29.

14. Riley RL. Airborne infection. Am J Med 1974;57:466-475.

15. American Society of Heating, Refrigerating, and Air Conditioning Engineers. Ventilation for Acceptable Indoor Air Quality Atlanta, GA: ASHRAE, Inc.; 1989. Standard 62.

16. Woods JE, Rash DR. Heating, ventilation, air conditioning systems: the engineering approach to methods of control. In: Kundsin RB, ed. Architectural Design and Indoor Microbial Pollution. New York, NY: Oxford University Press; 1988:123-153.

17. DiPerri G, Cadeo G, Costelli F, et al. Transmission of HIVassociated tuberculosis to healthcare workers. Infect Control Hosp Epidemiol 1993;14:67-72.

\title{
OSHA Issues Guidelines for Enforcement of TB Protection Requirements
}

\section{Michael Decker, MD, MPH SHEA Liaison to OSHA}

In September, the Occupational Safety and Health Administration (OSHA) shared a draft "Enforcement Policy and Procedures for Occupational Exposure to Tuberculosis" with a small group of healthcare industry experts, who discussed issues related to tuberculosis (TB) control. The Society for Hospital Epidemiology of America and others submitted additional comments later that month. On October 18, 1993, OSHA issued the enforcement guidelines to their staff, regional and state offices, and the public. The enforcement guidelines are effective immediately, except that a 90-day grace period was allowed to achieve compliance with the respiratory protection component. Key elements of the TB protection requirements are outlined below; we will try to provide more detailed guidance soon.

Employees who enter rooms containing patients with known or suspected infectious TB or who perform high-risk procedures on such individuals must use National Institute for Occupational Safety and Health-approved high-efficiency particulate air (HEPA) respirators. The need to use such respirators automatically requires the establishment of a complete Respiratory Protection Program, as delineated in 29 CFR 1910.134, including qualitative (irritant fume) or quantitative fit testing. As always, employers would be expected to implement engineering controls or work rules, to the extent possible, to abate hazards that required the use of personal protective devices.

The enforcement guidelines clarify that records of employee exposure to TB, of TB skin testing, and of medical evaluations and treatment are subject to OSHA recordkeeping rules. Any positive TB skin test in an employee (other than pre-employment) would be rebuttably presumed to be occupational and would have to be recorded on the OSHA $200 \log$, as would any clinical TB disease in employees. Medical management of such conditions would be the responsibility of the employer. Employers are expected to establish programs for the early identification of individuals with active $\mathrm{TB}$, periodic worker screening, and worker training.

Inspections for occupational exposure to TB will be conducted in response to employee complaints or as part of compliance inspections otherwise being conducted in healthcare institutions or other settings of elevated TB risk, as delineated by Centers for Disease Control and Prevention in its TB advisories. Citations will be issued for violations of OSHA standards, particularly including 29 CFR 1910.134 and the General Duty clause.

If OSHA's history with respect to the Bloodborne Pathogen Standard offers an example, it seems likely that enforcement of TB protection under the General Duty clause eventually would be replaced by development of a specific tuberculosis standard. 